Thomas Backer-Grøndahl, ph.d. Human meningiomas: Histopathology, brain invasion, and prognosis. Utgår fra Institutt for laboratoriemedisin, barne- og kvinnesykdommer. Disputas 19.6. 2014.

Bedømmelseskomité: Hrvoje Miletic, Haukeland universitetssykehus, Helse Bergen, Magnus Tisell, Sahlgrenska Universitetssjukhuset, Göteborg, Sverige, og Mette H. Moen, Norges teknisk-naturvitenskapelige universitet.

Veiledere: Sverre Helge Torp, Christina Vogt og Stein Harald Sundstrøm.

\section{Universitetet i Tromsø Norges arktiske universitet http://www2.uit.no/ikbViewer/ page/startsida/forskning/doktorgrader}

Oddveig G. Rikardsen, ph.d. Prognostic markers in oral squamous cell carcinoma. Utgår fra Institutt for klinisk medisin. Disputas 20.6. 2014

Bedømmelseskomité: Karin Nylander, Medical Biosciences, Umeå Universitet, Sverige, Hans Jørgen Aarstad, Klinisk institutt 1, Det medisinsk-odontologiske fakultet, Universitetet i Bergen, og Maria Perander, Institutt for medisinsk biologi, Det helse vitenskapelige fakultet, Universitetet i Troms $\varnothing$ - Norges arktiske universitet.

Veiledere: Sonja Eriksson Steigen, Lars Uhlin-Hansen, Gunbjørg Svineng og Elin Synnøve Hadler-Olsen.

\title{
Are Holen utnevnt til ridder av 1. klasse
}

\author{
Professor Are Holen (f. 1945) er utnevnt til Ridder av 1. klasse av St. Olavs Orden for sin samfunnsnyttige \\ innsats.
}

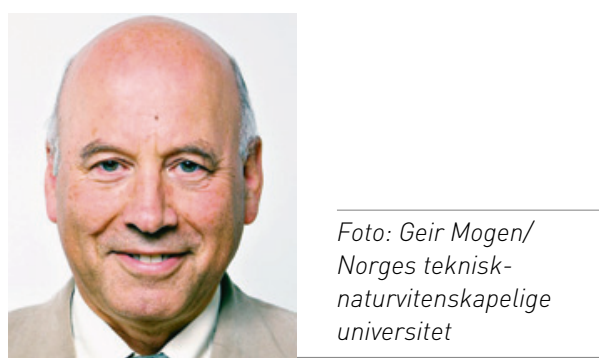

Holen er fra Oslo, ble cand.psychol. i 1972, cand.med. i 1978 og dr.med. i 1990, alt ved Universitetet i Oslo. Han har vært ansatt ved Det medisinske fakultet ved Norges teknisk-naturvitenskapelige universitet siden 1993. Som professor i medisinske atferdsfag har han vært ansvarlig for kurs for å bedre kommunikasjonen mellom helsepersonell og pasienter. Innen undervisning har han vært en sentral skikkelse i utforming og implementering av problembasert læring ved Det medisinske fakultet, og han har også vært sentral i utviklingen av en læringsaktivitet for tverrfaglig samarbeid (Eksperter i team) på hele Norges teknisk-naturvitenskapelige universitet. Som psykolog og lege har han vært med på å skape et internasjonalt utdanningstilbud for psykisk stress- og krisehåndtering gjennom kollegastøtte for helsepersonell, prester, politifolk, militære og brannfolk.
Are Holens forskning har gitt viktige bidrag til å forstå hvordan traumatisk stress påvirker helse og livsløp, slik som ved plutselig tap av ektefelle, langtidsvirkninger hos barn som er rammet av akutt leukemi og ettervirkninger blant soldater som har vært i fredsbevarende oppdrag. Han deltok selv i behandling og oppfølging av de overlevende etter West Vanguard-ulykken i Nordsjøen i 1986. Doktorgraden hans omhandlet de overlevende etter Alexander Kiellandulykken i 1980. Med denne bakgrunnen har han gjort en stor innsats blant katastrofeofre og har blant annet veiledet ambassadepersonell etter jordskjelvet i Kobe i 1995, hatt ansvaret for oppfølging av 80 bankansatte på Manhattan etter 11. september 2001 og bistått i forbindelse med tsunamien i 2004. Etter terrorhandlingen på Utøya 22. juli 2011 har han vært veileder for psykoterapeuter som støtter overlevende.

Holen har vært prodekan for undervisning og har hatt en rekke sentrale lederstillinger ved Det medisinske fakultet. I tillegg har han vært leder for Institutt for nevromedisin.

I 1966 grunnla han Acem, en frivillig organisasjon for meditasjon, gruppepsykologi og kultur som etter hvert har utviklet seg til å bli en internasjonal organisasjon. Han var også en av grunnleggerne av kulturtidsskriftet Dyade i 1971.

Lars Jacob Stovner lars.stovner@ntnu.no 